\title{
Precipitation of LDL with Sulphopolyanions: A Comparison of Two Methods for LDL Cholesterol Determination
}

\author{
By G. Assmann, H.-U. Jabs, W. Nolte and H. Schriewer \\ Institut für Klinische Chemie und Laboratoriumsmedizin (Zentrallaboratorium) \\ der Medizinischen Einrichtungen der Westfälischen Wilhelms-Universität, Münster
}

(Received September 28, 1983/August 22, 1984)

Summary: Two commercially available tests for the determination of LDL cholesterol were compared. The determination principle lies in the precipitation of LDL using heparin (Merck, Darmstadt test) or using polycyclic surface activated anions (bioMérieux test), as well as ascertaining LDL cholesterol by subtracting cholesterol in the supernatant from total cholesterol (Merck, Darmstadt test) or the direct determination of cholesterol in the redissolved precipitate (bioMérieux test).

Regression analysis of the LDL cholesterol values obtained by precipitation and the LDL cholesterol values obtained by the combination of ultracentrifugation and HDL cholesterol determination (cholesterol in the $\mathrm{d}$ $>1.006 \mathrm{~kg} / \mathrm{l}$ ultracentrifugation fraction-HDL cholesterol) resulted in a good correlation (precipitation using polycyclic surface activated anions: $\mathrm{r}=0.95, \mathrm{y}=1.01 \mathrm{x}-0.14, \mathrm{n}=34$; heparin precipitation: $\mathrm{r}=0.94$, $y=0.86 x+0.10, n=28$ ). In sera containing triglycerides ranging from $2.28 \mathrm{mmol} / 1$ to $10.9 \mathrm{mmol} / 1$ there was an adequate agreement between the values obtained by precipitation with polycyclic surface activated anions and those of the reference method $(r=0.94, y=0.9 x+0.47, n=51)$, whereas the data obtained by heparin precipitation clearly deviated from the data of the reference method $(r=0.69, y=0.75 x+0.003, n=32)$.

\section{Präzipitation von LDL mit Sulfopolyanionen:}

Vergleich zweier Methoden zur LDL-Cholesterin-Bestimmung

Zưsammenfassung: Zwei kommerziell erhältliche Testmethoden zur Bestimmung von LDL-Cholesterin wurden verglichen. Das Bestimmungsprinzip beruht auf der Fällung von LDL mittels Heparin (Testmethode Merck, Darmstadt) odẹr mittels eines polyżyklischen oberflächenaktiven Anions (Testmethode bioMérieux) und der Ermittlung von LDL-Cholesterin aus der Differenz Gesamtcholesterin-Cholesterin im Fällungsüberstand (Testmethode Merck, Darmstadt) oder aus der direkten Bestimmung von Cholesterin im wieder aufgelösten Präzipitat (Testmethode bioMérieux).

Die Regressionsanalyse der durch Präzipitation ermittelten LDL-Cholesterinwerte und der durch die Kombinätion von Ultrazentrifugation und $\mathrm{HDL}$-Cholesterin Bestimmung ermittelten LDL-Cholesterinwerte (Cholesterin in der $\mathrm{d}>1.006 \mathrm{~kg} / \mathrm{l}$ Ultrazentrifugationsfraktion - HDL-Cholesterin) lieferte bei beiden Präzipitationsverfahren eine gute Ubereinstimmung zwischen den durch die Fällung ermittelten Werten und den Werten des Referenzierfahrens (Fällung mit polyzyklischen oberflächenaktiven Anionen: $r=0,95, y=$ $1,01 x-0,14, n=34$; Heparin-Fällung: $r=0,94, y=0,86 x+0,10, n=28$ ). In hypertriglyceridämischen Seren mit Triglyceridgehalten zwischen 2,28 und $10,9 \mathrm{mmol} / \mathrm{l}$ wurde nur mit den mittels Fällungsverfahren mit polyzyklischen oberflächenaktiven Anionen und mittels Referenzverfahren ermittelten Werten eine adäquate Úbereinstimmung beobachtet $(\mathrm{r}=0,94, \mathrm{y}=0,9 \mathrm{x}+0,47, \mathrm{n}=51)$, während die mit dem Heparin-Fällungsverfahren ermittelten Daten deutlich von denen des Referenzverfahrens abwichen $(x=0,69, y=0,75 x$ $+0,003)$. 


\section{Introduction}

Previous epidemiological studies have shown that an elevated level of low density lipoproteins (LDL) represents a risk factor for coronary heart disease (1, 2). There is, however, as yet no method for the exact determination of LDL cholesterol under routine conditions. Determination of LDL cholesterol following isolation using ultracentrifugation is timeconsuming and technically elaborate, limited in capacity and hence unsuitable for routine investigations. LDL cholesterol is usually calculated by means of the Friedewald formula (3). The Friedewald formula does, however, presuppose a constant choleste$\mathrm{rol} /$ triglyceride relationship in the VLDL. However, this constancy is only given in normotriglyceridaemic sera and sera of individuals without dyslipoproteinaemia.

Recently commercial tests have been developed for the analysis of LDL cholesterol following selective precipitation of LDL with sulphopolyanions (polyvinylsulphate, heparin, polycyclic surface activated anions). This present study examines the accuracy of two commercially available LDL cholesterol determination methods using heparin and using polycyclic surface activated anions when applied to normo- and hypertriglyceridaemic sera.

\section{Materials and Methods}

Sample material

As test material we used fresh sera from the test series "Prospective epidemiological study in company employees in Westfalia" (4).

\section{Determination of LDL cholesterol}

\section{Precipitation with heparin}

For this analysis we used the Merck, Darmstadt, test order no.: 14992.

Test kit precipitation reagent $(1000 \mu \mathrm{l})$ was pipetted into an incubation tube (Sarstedt no.: 52690) containing $100 \mu \mathrm{l}$ serum. This mixture was incubated for 10 minutes at room temperature and then centrifuged for 15 minutes in an Eppendorf centrifuge 3200. Immediately after centrifugation $100 \mu \mathrm{l}$ of the supernatant were used for cholesterol determination. Cholesterol was determined enzymatically using the cholesterol oxidase/4-aminophenazone phenol method contained in the test kit. LDL cholesterol was determined as the difference between total cholesterol and cholesterol in the supernatant.

\section{Precipitation with polycyclic surface activated anions}

For this analysis we used the bioMérieux test, "LDL cholesterol/ phospholipids", order no.: 61532, 69260 Charbonnières Les Bains, France.

In an incubation tube (Sarstedt no.: 52690) $50 \mu \mathrm{l}$ serum and 1000 $\mu l$ test kit precipitation reagent $(0.4 \mathrm{~g} /$ polycyclic surface activated anion, $0.8 \mathrm{~g} / \mathrm{l}$ polycondensated polycyclic surface activated anion, $12.4 \mathrm{mmol} / \mathrm{/}$ polysubstituted dioxan, $25 \mathrm{mmol} / \mathrm{h}$ imidazole buffer, pH 6.10) were mixed. This mixture was incubated for 30 minutes at $2-8{ }^{\circ} \mathrm{C}$ and the precipitate was centrifuged for $5 \mathrm{~min}$ utes in an Eppendorf centrifuge 3200 . The supernatant was discarded and the precipitate was mixed with $500 \mu l$ of the dissolvent solution contained in the test kit (trisodium citrate, $0.15 \mathrm{mmol} / \mathrm{h}$; $\mathrm{NaCl}, 0.11 \mathrm{mmol} / \mathrm{l}$ ). The mixture was incubated for 10 minutes at $37^{\circ} \mathrm{C}$, then cholesterol was determined enzymatically (bio Mérieux, Cholestérol enzymatique PAP250, order no.: 61225). For determination of cholesterol in the supernatant we used the cholesterol oxidase 4-aminophenazone phenol method (Boehringer Mannheirn, Monotest cholesterol order no.: 237574).

Preparative isolation of lipoproteins by ultracentrifugation

Preparative isolation of lipoproteins by ultracentrifugation was performed as described previously in detail (5).

Determination of HDL cholesterol

HDL cholesterol was determined by measuring cholesterol in the supernatant (Boehringer Mannheim, Monotest Cholesterol High Performance, order no.: 237574) following precipitation of apolipoprotein B-containing lipoproteins in serum using phosphotungstic acid/ $\mathrm{MgCl}_{2}$ (6).

\section{Determination of triglycerides}

Triglycerides were determined enzymatically using the enzymatic triglyceride assay after enzymatic hydrolysis (Boehringer Mannheim "Test Combination Triglyceride Vollenzymatischer UVTest", order no.: 240052).

\section{Results}

Accuracy of the LDL cholesterol determination in normal serum

Regression analysis of the LDL cholesterol values ascertained by precipitation with polycyclic surface activated anions $(y)$ and the LDL cholesterol values ascertained by a combination of ultracentrifugation and HDL cholesterol determination using phosphotungstic acid/ $\mathrm{MgCl}_{2}$ precipitation (x) (= cholesterol in the $\mathrm{d}>1.006 \mathrm{~kg} / \mathrm{l}$ ultracentrifugation fraction - HDL cholesterol) resulted in a good correlation $(\mathrm{r}=0.95, \mathrm{y}=1.01 \mathrm{x}-0.14, \mathrm{n}=34)$ (fig. 1). Similar results were obtained when LDL cholesterol was determined as the difference between total cholesterol and cholesterol in the supernatant following precipitation of LDL with polycyclic surface activated anions $(r=0.97, y=0.98 x-0.04, n=43)$.

The data obtained using precipitation with heparin also resulted in a good correlation to the values of the reference method $(\mathrm{r}=0.94, \mathrm{y}=0.86 \mathrm{x}+0.1, \mathrm{n}$ = 28) (fig. 2).

In order to check the influence of intermediate density lipoproteins (IDL, $d=1.006=1.019 \mathrm{~kg} /$ ) on the accuracy of LDL precipitation, simultaneous tests were performed in which $\mathrm{LDL}$ cholesterol was 

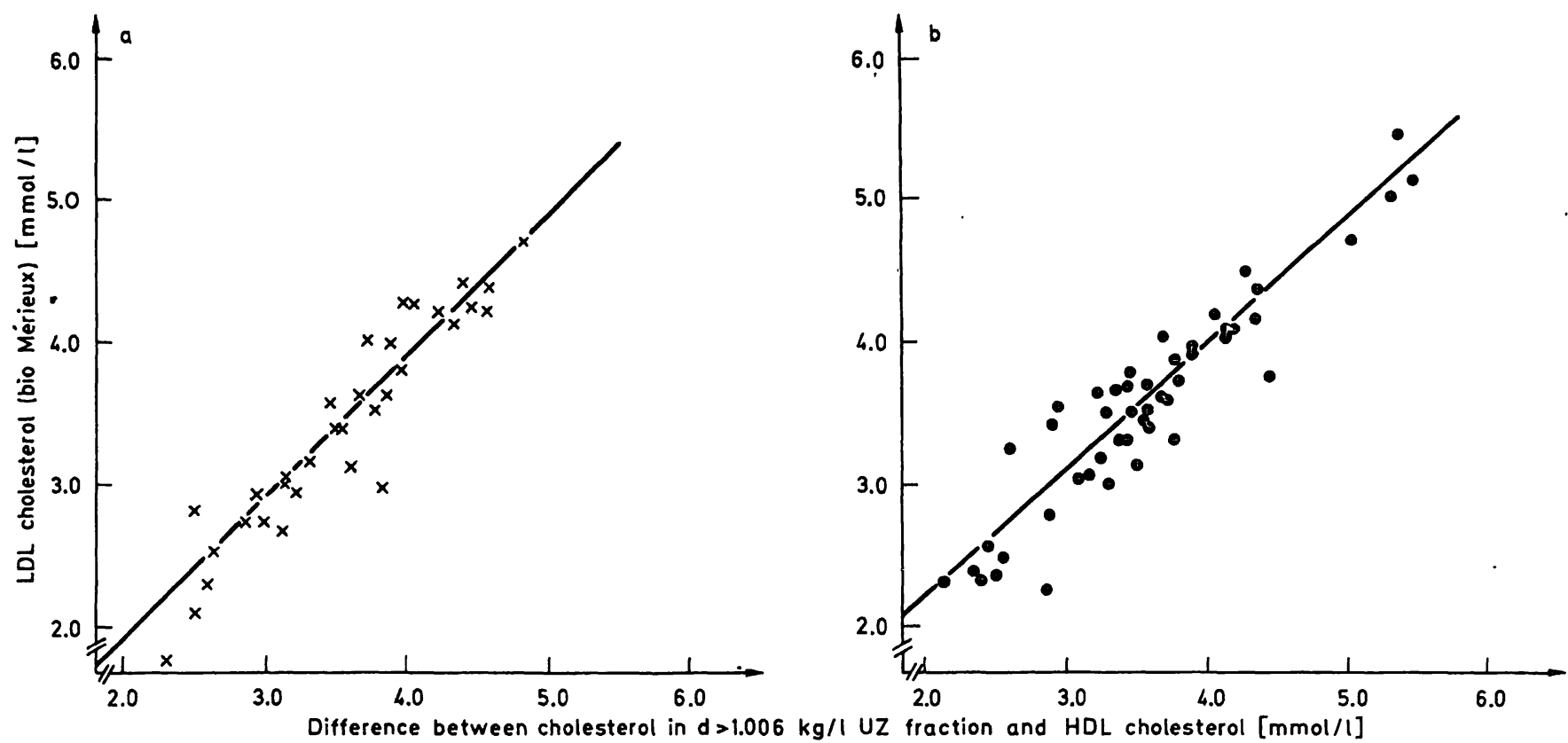

Fig. 1. Regression analysis of $\mathrm{LDL}$ cholesterol values determined by a combination of ultracentrifugation (d $>1.006 \mathrm{~kg} / \mathrm{l})$ and $\mathrm{HDL}$ cholesterol determination $(x)$ and LDL cholesterol values determined by precipitation with polycyclic surface activated anions (y)

a) sera with triglycerides $<2.28 \mathrm{mmol} / \mathrm{h}(\mathrm{r}=0.95, \mathrm{y}=1.01 \mathrm{x}-0.14, \mathrm{n} \doteq 34)$.

b) sera with triglycerides ranging from $2.28 \mathrm{mmol} / /$ to $10.9 \mathrm{mmol} / \mathrm{l}(\mathrm{r}=0.94, \mathrm{y}=0.9 \mathrm{x}+0.47, \mathrm{n}=51)$.
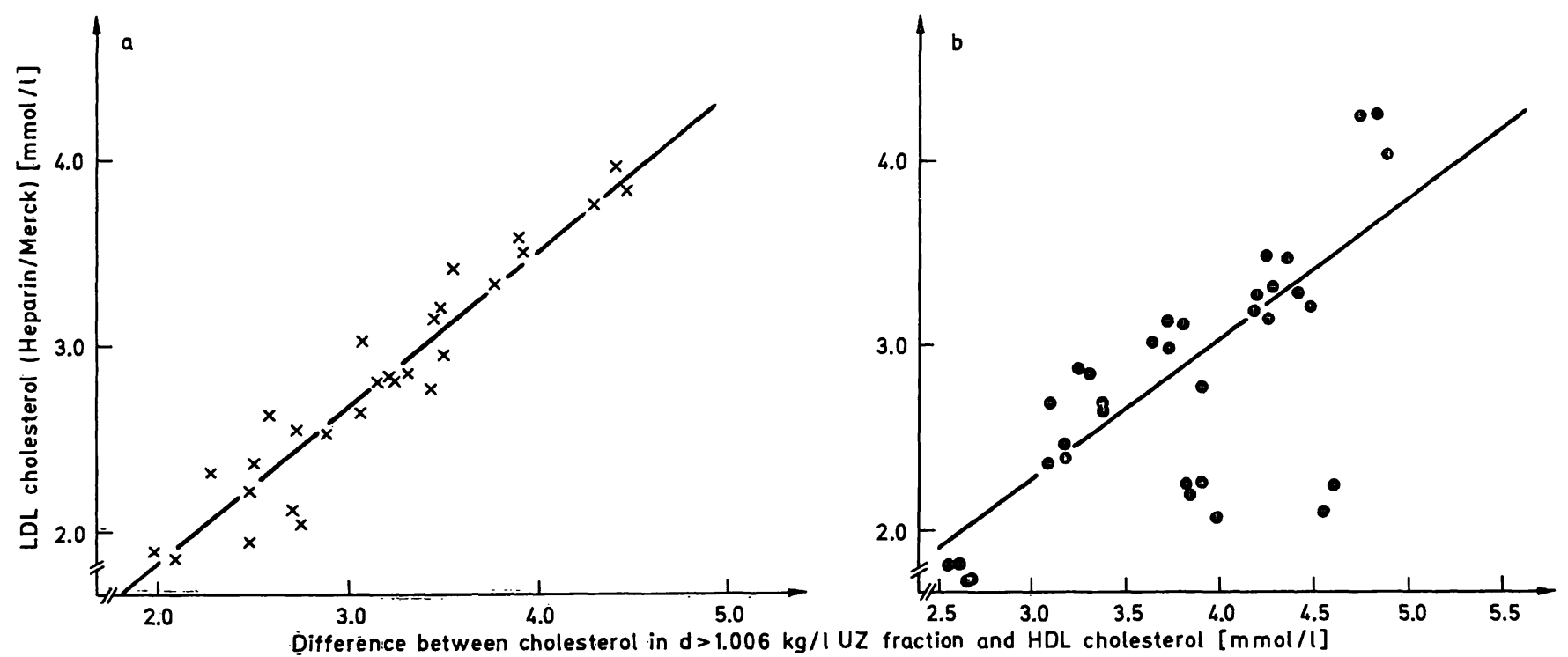

Fig. 2. Regression analysis of LDL cholesterol values determined by a combination of ultracentrifugation (d $>1.006 \mathrm{~kg} / \mathrm{l})$ and $\mathrm{HDL}$ cholesterol determination $(x)$ and LDL cholesterol values determined by precipitation with heparin $(y)$.

a) sera with triglycerides $<2.28 \mathrm{mmol} / \mathrm{h}(\mathrm{r}=0.94, \mathrm{y}=0.86 \mathrm{x}+0.1, \mathrm{n}=28)$.

b) sera with triglycerides ranging from $2.28 \mathrm{mmol} / \mathrm{l}$ to $4.2 \mathrm{mmol} / \mathrm{r}=0.69, \mathrm{y}=0.75 \mathrm{x}+0.003, \mathrm{n}=32)$.

determined as the difference between cholesterol in the $d>1.019 \mathrm{~kg} / \mathrm{l}$ ultracentrifugation fraction and HDL cholesterol. Comparison of the paired values of both methods and the reference method showed a slight deterioration (polycyclic surface activated anions: $\mathrm{r}=0.95, \mathrm{y}=1.12 \mathrm{x}+0.31, \mathrm{n}=18$; heparin: $\mathrm{r}=0.83, \mathrm{y}=0.67 \mathrm{x}+0.34, \mathrm{n}=18$ ).
Accuracy of LDL cholesterol determination in hypertriglyceridaemic sera

In order to assess the influence of hypertriglyceridaemia on the accuracy of LDL determination, additional tests were carried out with sera containing triglycerides ranging from $2.28 \mathrm{mmol} / /$ to $10.9 \mathrm{mmol} /$ (mean: $8.05 \mathrm{mmol} / \mathrm{l}$, median: $7.91 \mathrm{mmol} / \mathrm{l}$ ). Even in 
hypertriglyceridaemic sera there was a satisfactory correlation between the values obtained using the precipitation method with polycyclic surface activated anions ( $y$ ) and those of the reference method (cholesterol in the $\mathrm{d}>1.006 \mathrm{~kg} / \mathrm{l}$ ultracentrifugation fraction-HDL cholesterol) $(x)(r=0.94, y=0.9 x$ $+0.47, n=51$ ) (fig. 1). However, data obtained using the heparin precipitation method clearly deviated from the data of the reference method $(r=0.69$, $y=0.75 x+0.003, n=32$ ) (fig. 2). The deviation of the data from the regression line was obviously not related to the triglyceride values.

\section{Coprecipitation of VLDL}

In sera containing high concentrations of triglycerides, the only method showing a close correlation with the reference method was precipitation using polycyclic surface activated anions. This method was therefore further analysed for possible precipitation of VLDL. This was studied in sera with triglyceride concentrations ranging from 0.57 to $6.16 \mathrm{mmol} / \mathrm{l}$. In order to ascertain the extent of VLDL coprecipitation, VLDL cholesterol values calculated after LDL precipitation $(y)$ (= cholesterol in the supernatant following LDL precipitation-HDL cholesterol) were compared with VLDL cholesterol values calculated after ultracentrifugation (x) (= total choleste-

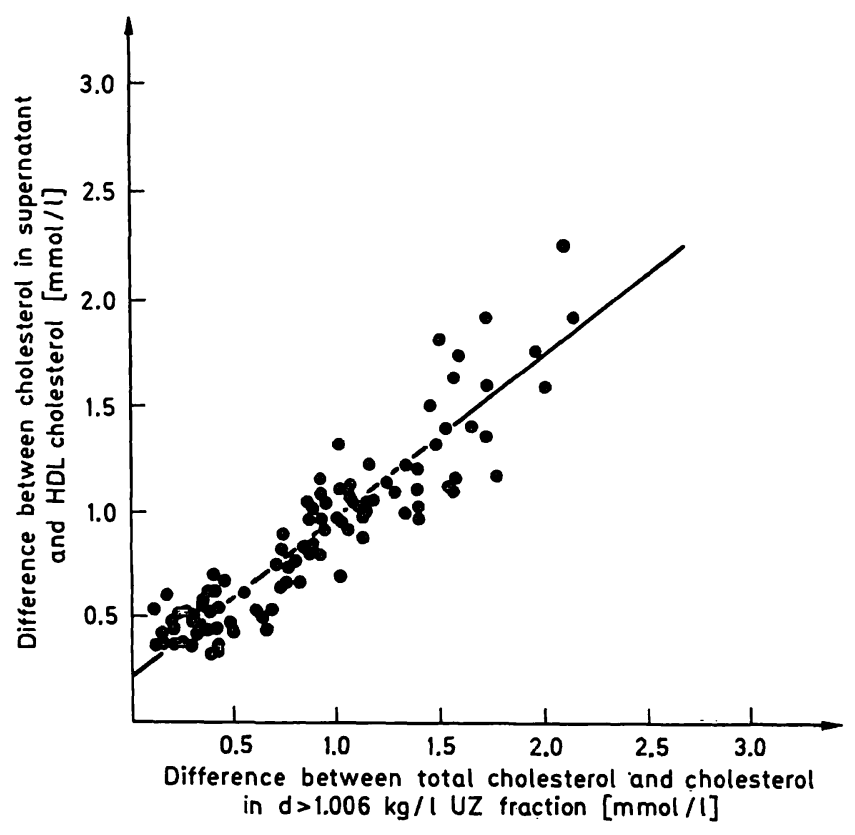

Fig. 3. Regression analysis of VLDL values following ultracentrifugation (difference between total cholesterol and cholesterol in the $d>1.006 \mathrm{~kg} / \mathrm{l}$ ultracentrifugation fraction) $(x)$ and VLDL cholesterol values following precipitation with polycyclic surface activated anions (difference between cholesterol in the supernatant and HDL cholesterol) (y) $(r=0.93, y=0.77 x+0.2, n=110)$. rol-cholesterol in the $\mathrm{d}>1.006 \mathrm{~kg} / \mathrm{l}$ ultracentrifugation fraction). Regression analysis resulted in a good correlation between VLDL cholesterol values obtained by precipitation using polycyclic surface activated anions and the values obtained by the reference method $(r=0.93, y=0.77 x+0.2, n=110)$ (fig. 3).

As shown in figure 3 in sera with VLDL cholesterol values $<0.5 \mathrm{mmol} / \mathrm{l}$ data obtained from the precipitation method were on the average slightly higher than the data obtained from the reference method while in sera with VLDL cholesterol values $>1.3$ $\mathrm{mmol} / \mathrm{/}$ data obtained from the precipitation method were on the average slightly lower than the data obtained from the reference method. In sera with VLDL cholesterol values $>0.5<1.3 \mathrm{mmol} / 1$ there was a good agreement between the values obtained from the precipitation method and the values obtained from the reference method $(y=0.97 x+$ $0.01, \mathrm{n}=46$ ).

\section{Discussion}

The precipitation methods examined in this study are in principle based on the tests of Bernfeld et al. who evaluated the precipitation of LDL using naturally occurring sulphate-containing polysaccharides (7). It has been shown that the completeness of precipitation is dependent on the sulphate content per monomer of the polysaccharides used and the degree of polymerisation. In naturally occurring polysaccharides such as heparin the degree of polymerisation and the sulphate content of the molecules vary within certain limits. In synthetic structures, however, a defined sulphate content per monomer and a relatively constant degree of polymerisation can be produced. Consequently, when using heparin, some variation with regard to the precipitation properties can be expected depending on the molecular weight and the origin of the substance.

The main problem in the quantification of LDL is the fact that LDL are a heterogeneous group of particles with varying composition, varying metabolism and varying physico-chemical properties. An additional problem is that with hyper- or dyslipoproteinaemias considerable deviations from the average relative composition of LDL occur. LDL in hypertriglyceridaemic individuals, for instance, are relatively rich in triglycerides $(8,9)$. A relative stability of the average cholesterol/triglyceride ratio of the LDL applies strictly speaking only to normotriglyceridaemic sera, to chylomicron free sera and to sera of individuals without dyslipoproteinăemia. The methods 
used for routine determination of LDL cholesterol, such as the Friedewald formula (3) or lipoprotein electrophoresis (10) basically presuppose a constant cholesterol/triglyceride ratio in the LDL. Therefore, application of these methods is strictly speaking only meaningful in normotriglyceridaemic sera.

It is to be expected that the selectivity of the LDL precipitation using sulphopolyanions depends on the relative composition of LDL and VLDL particles. Our results show that with polycyclic surface activated anions the LDL are apparently only strictly selectively precipitated in a VLDL cholesterol range of $0.5 \mathrm{mmol} / 1$ to $1.3 \mathrm{mmol} / 1$. In sera with lower VLDL cholesterol content the precipitation of LDL is prob- ably not complete, and in sera with a higher VLDL cholesterol content small amounts of VLDL cholesterol are coprecipitated.

According to our results both precipitation methods can be applied to normotriglyceridaemic sera and produce LDL cholesterol values comparable to the reference method. In hypertriglyceridaemic sera, the method using polycyclic surface activated anions was sufficiently selective for the precipitation of LDL but its practical use is reduced because of its relatively low linearity. It is concluded that the heparin method for the determination of LDL cholesterol gives inaccurate results in hypertriglyceridaemic sera and, therefore, is not suitable for routine purposes.

\section{References}

1. Gofman, J. W., Lindgren, F., Elliot, A., Mantz, W., Hewitt, J., Strisower, B., Herring, B., Herring, V. \& Lyon, T. P. (1950) Science 111, 166-171.

2. Scanu, A. M. (1978) Ann. Clin. Lab. Sci. 8, 79-83.

3. Friedewald, W. T., Levy, R. I. \& Fredrickson, D. S. (1972) Clin. Chem. 18, 499-509.

4. Assmann, G., Oberwittler, W., Schulte, H., Schriewer, H., Funke, H., Epping, P. H. \& Hauss, W. H. (1980) Internist 21, 446-459.

5. Schriewer, H., Konert, U. \& Assmann, G. (1984) J. Clin. Chem. Clin. Biochem. 22, 35-40.

6. Assmann, G., Schriewer, H., Schmitz, G. \& Hägele, E. O. (1984) Clin. Chem. 29, 2026-2030.

7. Bernfeld, P., Nisselbaum, J. S., Berkeley, B. J. \& Hanson, R. W. (1960) J. Biol. Chem. 235, 2852-2859.

8. Breckenridge, W. C., Little, J. A., Steiner, G., Chow, A. \& Poapst, M. (1978) N. Engl. J. Med. 298, 1265-1273.

9. Miller, N. E., Rao, S. N., Alaupovic, P., Noble, N., Slack, K., Brunzell, D. \& Lewis, B. (1981) Eur. J. Clin. Invest. 11, 6976.

10. Wieland, H., Niazi, M., Bartholomé, M. \& Seidel, D. (1980) Ärztl. Lab. 26, 257-266.

Prof. Dr. G. Assmann Institut für Klinische Chemie und Laboratoriumsmedizin (Zentrallaboratorium) der Med. Einrichtungen der Westfälischen Wilhelms-Universität Albert-Schweitzer-Straße 33 D-4400 Münster 
